\title{
Redesigning corporate governance: lessons learnt from the global financial crisis
}

\author{
Martin Hilb
}

Published online: 4 February 2010

(C) Springer Science+Business Media, LLC. 2010

\section{Introduction}

The global financial and economic crisis has uncovered four major weaknesses in the direction and control of many large, publicly traded companies, especially in the financial services sector.

Firstly: With only a few exceptions, among them South Africa, most countries have, contrary to the OECD principles, adopted the Anglo-Saxon corporate governance guidelines, targeting the maximization of shareholder value.

Secondly: In contrast, successful companies in the financial services sector such as family companies, partnerships and glocal companies, have only been affected to a limited extent by the financial crisis. Those companies most affected by the crisis did not dispose of holistic, measurable success criteria that added simultaneous value to customers, owners, employees and the society.

Thirdly: As a consequence, the vast majority of variable compensation packages were set for a short-term period, mainly yearly and using one often irrelevant financial ratio as opposed to non-financial ratios and competitive benchmarks. Furthermore, the integration of board, CEO and personnel compensation concepts has been largely neglected.

Fourthly: Accordingly, holistic monitoring and risk management concepts have been largely disregarded on the board level of many large organizations.

\footnotetext{
M. Hilb ( $($ )

Institute for Leadership and Human Resource Management/Center for Corporate Governance, University of St. Gallen, Dufourstrasse 40a, 9000 St. Gallen, Switzerland e-mail: Martin.Hilb@unisg.ch
} 
Four broad recommendations, each including two lessons for an improved corporate governance of large international publicly traded companies can be deducted from these four weaknesses.

\section{Keep it situational}

Corporate Governance has to be adapted periodically to the changing conditions on an international, national, and corporate level.

\subsection{First lesson}

On a national level, it is necessary for corporate governance guidelines to be challenged. Several corporate scandals have provoked a precipitous adoption of the shareholder value maximization dictum. The related focus on quarterly figures is one of the main drivers of the financial crisis. This should be replaced by a holistic approach. Companies can compete and succeed with sustainable fundamentals only if simultaneous value is added to shareholders, customers, employees and the society.

\subsection{Second lesson}

On an international level, the direction and control of subsidiaries, the so-called subsidiary governance, has to be critically reconsidered. Many companies that have been strongly affected by the financial crisis have failed in the field of subsidiary governance. Complex structured companies in the international arena should not govern their subsidiaries by "puppet boards" which neither direct nor control subsidiary management. They should be composed of competent, committed and independent local board teams. Those subsidiary boards should each be chaired by a member of the board of directors and not by a member of the management team of the above operative unit, as it is now being commonly practiced.

\section{Keep it strategic}

The financial crisis has shown that many boards do not have the know-how required for an effective direction and control of management in times of crisis. Power structures on the board level have often been designed in such a way that the question of Peter Senge arises: "How can a team of individual IQs above 120 have a collective IQ of 60 ?", became reality.

\subsection{Third lesson}

The board of directors should possess in breadth the same market/product and functional know-how as top management, to be able to direct and control effectively and efficiently. Complementary team roles such as the roles of a critical thinker, a 
controller or a creative thinker have to be present on the board. Furthermore, each member should play the role of one stakeholder such as customer, shareholder, employee and society/environment.

\subsection{Fourth lesson}

The sustainability of the company's success cannot be ensured by a one-dimensional way of focusing on top executive value and quarterly results. Thus, the board has to develop holistic measures for the company success that differentiates the company from its competitors on the customer, owner, employee and societal level. The board should periodically measure and review success in each of the four dimensions.

\section{Keep it integrated}

The crisis has provided evidence that the globally dominant Anglo-Saxon soft governance laws has caused negligence for the softer dimensions of companies, including the successful selection, evaluation, remuneration, development and succession of members of the board of directors and especially of the managing board. However, misguided incentives and inadequate succession planning became realities within the current crisis.

\subsection{Fifth lesson}

The financial crisis has confirmed that a company needs an integrated board, management, and personnel compensation concept that is based on internal, external and company performance equity. In securing the success-based equity, the variable compensation packages have to account for both the long term and the short term success horizon of the company (e.g. for boards: $100 \%$ of bonuses on a 3 year basis, for CEO: $50 \%$ of bonuses on a 3 year basis or $50 \%$ on a 1-year basis). The rating has to be based on both financial ratios (e.g. EVA) as well as non-financial success indicators (e.g. customer loyalty). These in turn, have to be compared regularly to those of relevant competitors.

\subsection{Sixth lesson}

Succession planning of the board and management represent one of the main weaknesses and are sources of risk for many companies. Based on a sustainable, competent succession planning system, the board of directors therefore, should nominate periodically and confidentially successors for all key positions on the board and managerial level.

\section{Keep it controlled}

Last but not least, the global financial crisis has shown that many boards exhibit weaknesses in terms of controlling, ethical compliance and risk management. 


\subsection{Seventh lesson}

The effective review of internal and external auditing; the quality of financial reporting; holistic risk management and internal control; IT governance and communication as well as legal and ethical compliance are some of the most important board tasks.

The crisis has illustrated that for publicly traded companies, the greatest area for improvement is not within legal, but within ethical compliance. This implies that not everything that is abided by law corresponds to legitimate action. Furthermore, it has to be understood that codices for proper behavior are worthless if they merely exist, but are not followed by the top decision makers in the company.

\subsection{Eighth lesson}

The well-known victims of the financial crisis did not conduct periodic, objective and comprehensive evaluations with regards to the direction and control of the company. Therefore, companies should not await new regulations, but proactively initiate a periodic multi-dimensional evaluation of the board's performance from the viewpoint of directors, (core) shareholders and management. That can help not just to overcome the current crisis, but also to prevent future crises.

\section{Conclusion}

\subsection{Search for sustainability and common sense}

In conclusion: "Common sense is the least common of all senses." The current global financial crisis has confirmed the Oscar Wilde quotes: Common sense means that money should serve people, and not the other way around. This attitude should be kept in mind also when new corporate governance guidelines are developed for directing and controlling companies. Thus, whether companies rank among losers or winners of the financial crisis depends to a large extent on their willingness and ability to consider within a sustainable concept of multiple constituencies rather than just the interest of top executives and shareholders, but always add simultaneous value to customers, shareholders, employees, and society.

This special issue includes the following four research papers that have been selected as the four best presented at the 5th International Research Workshop on Corporate Governance at the European Institute for Advanced Studies in Management, in Brussels November 2008:

1. Keep it situational:

"Corporate Governance and Corporate Social Responsibility" by Sharon Kemp, Swinburne University of Technology (Australia)

"The financial and reputational success of the organization and its members is out of balance with the human and social costs and benefits. Respondents 
confirmed that board members and senior management should willingly provide information about the corporation and its activities to its stakeholders, that information and data should be transparent, the true extent of director remuneration should be revealed and that financial reporting should be true and accurate. Board members and senior management can be assisted to operate in a way that observes socially responsible values and balances the obligation for profit maximization with corporate social responsibilities (CSR). This study provides steps that organizations can take to achieve a balance of intellect, emotionality and sense of purpose and therefore realize their corporate social responsibility. The results of this empirical and secondary research suggest a method that may be used to make board members and senior managers more aware of their corporate social responsibilities and curtail corporate misbehaviour where the introduction of a range of new regulations has had little effect."

\section{Keep it strategic:}

"The Credit Crunch, Investor Activists and Corporate Strategy"

by Coral Ingley, Auckland University of Technology (New Zealand)

Jens Mueller, Waihato Management School (New Zealand)

Graeme Cocks, Melbourne Busines School (Australia)

"The concept of stakeholder engagement is gaining increasing attention in the mainstream media and may feature as part of a corporation's strategy for corporate social responsibility. Not only are boards considering how they might engage with key stakeholders, but stakeholders are also pursuing greater participation in the strategic decisions of companies in which they invest. While this is an emerging concept in companies governed by unitary boards, as in North America, the issue of stakeholder engagement in various forms is also entering debate in other countries around the world. In general, however, the idea of shareholder or stakeholder representation on the boards of most UK and Commonwealth companies is anathema. Forces now influencing the development of strategies for stakeholder engagement and the rise of active investors include changing corporate governance rules which give investors more power in the election of directors, the increasing role of pension plans and hedge fund investment groups which have produced investors who keep a close eye on company performance and value, and a sluggish or turbulent stock market as a result of the financial crisis initiated by the credit crunch in the sub-prime mortgage markets. In this paper the phenomenon of stakeholder representation is examined and results of a recent survey conducted among a large sample of New Zealand directors are presented. The findings suggest that these traditionally-oriented boards are increasingly inwardly focused and are without an agenda for building and managing shareholder and stakeholder relations. Accordingly, such boards are unlikely to regard stakeholder engagement as a serious strategic issue and are thus also likely to miss 
significant opportunities in the changed business environment to benefit from stakeholder support."

3. Keep it integrated:

"Compensation of Non-Executive Directors"

by Peter Hahn, and Maziane Lasfer, both Cass Busines School, City University London (UK)

"Corporate governance guidelines in many countries do not specify the determinants of non-executive director compensation and the empirical evidence has only briefly and indirectly addressed this issue. We show that this question is fundamentally complex because a) whilst the roles of nonexecutive directors are relatively well stated, their actual contributions remain unclear, b) governance codes have not discussed the ways in which nonexecutive directors should undertake their roles and c) non-executive director contribution may be unobservable, and, therefore, their efforts, contribution and/or performance are difficult to measure. Nevertheless, we find the literature related to non-executive directors strongly supportive of some sort of remuneration that is a function of performance and effort to align nonexecutive directors with their duties and make boards more efficient in undertaking their duties."

4. Keep it controlled:

\section{"Does Strategic Corporate Performance Depend on Corporate Financial Architecture?" \\ by Irina Ivashkoskaya and Anastasia Stepanova, both Moscow Higher School of Economics (Russia)}

The "results could have some important policy implications for the firms in normal economic environment as well as in the period of global economic crisis. We found that the higher proportion of related ownership which indicates investors with significant voting power and the board's composition affect firm performance positively. The related shareholders and independent directors seem to add more value to firms while the impact of government ownership differs depending on the country. The emerging market's sample versus the one from developed countries proves the stronger influence of corporate financial architecture over performance."

\section{Author Biography}

Martin Hilb is a Professor of Business Administration at the University of St. Gallen in Switzerland. Martin Hilb has conducted research at the UBC in Vancouver and the MCSM in Sydney. He gained work experience with Nestlé SA in Switzerland, Martin \& Co. in Germany and Schering-Plough Corporation, USA, ultimately in the role of Director of Essex Chemie AG. Martin Hilb has consulted in the field of Board and HR Management in 60 countries. 